\title{
PROGRAM PENGEMBANGAN KEWIRAUSAHAAN INDUSTRI KREATIF DI STMIK AMIKOM PURWOKERTO
}

\section{CREATIVE INDUSTRY ENTREPRENEURSHIP DEVELOPMENT PROGRAM IN STMIK AMIKOM PURWOKERTO}

\author{
${ }^{1)}$ Dhanar Intan Surya Saputra, ${ }^{2)}$ Kuat Indartono, ${ }^{3)}$ Sitaresmi Wahyu Handani, \\ ${ }^{4)}$ Hellik Hermawan \\ 1,2,3,4)Teknik Informatika, STMIK Amikom Purwokerto \\ Jl. Letjen Pol Sumarto Watumas Purwanegara Purwokerto, Banyumas 53123 \\ Purwokerto, Jawa Tengah, Indonesia \\ Email: dhanarsaputra@amikompurwokerto.ac.id
}

\begin{abstract}
ABSTRAK
Mahasiswa dan Alumni STMIK Amikom Purwokerto dibentuk salah satunya untuk menjadi technopreneuryaitu sebagai pencipta lapangan pekerjaan berbasis teknologi, khususnya di bidang industri kreatif. Terdapat 16 sub sektor industri kreati, meliputi Aplikasi dan pengembangan permainan; Arsitektur; Desain Produk; Fesyen; Desain Interior; Desain Komunikasi Visual; Seni Pertunjukan; Film, Animasi dan Video; Fotografi; Kriya; Kuliner; Musik; Penerbitan; Periklanan; Seni rupa; Televisi dan Radio.Beberapa mahasiswa dan alumni STMIK Amikom Purwokerto telah merintis usaha yang pasarnya cukup menjanjikan, namun pada mereka mengalami permasalahan dalam pelaksanaannya yaitu masih memerlukan pembinaan dan pendampingan dalam mengelola usaha. Melalui kegiatan Program Pengembangan Kewirausahaan (PPK) Industri Kreatif maka diharapkan dapat memperluas jaringan pemasaran, kerjasama, penguatan manajemen dan mengenal bisnis model sehingga usaha yang ditekuni dapat berkembang dan bersaing di pasar.Adapun metode pelaksanaan PPK melalui tahapan yaitu sosialisasi, pendaftaran proposal bisnis, seleksi, dan pendampingan serta pelatihan. Diakhir kegiatan ini dihasilkan sebanyak 5 (lima) wirausaha baru yang telah mengikuti pendampingan dan pembinaan sehinga siap untuk berwirausaha dan bersaing dalam industri.
\end{abstract}

Kata kunci: Technopreneur; Wirausaha; Industri Kreatif

\begin{abstract}
Students and Alumni of STMIK Amikom Purwokerto were formed one of them to become a technopreneur, as a creator of employment based technology, especially in the field of creative industries. Creative industry is defined in 16 sub sectors, they are:(1) Application and Game Developer,(2) Architecture, (3) Interior design, (4) Visual Communication Design, (5) Product Design, (6) Fashion, (7) Film, Animation, and Video, (8) Photography, (9) Craft, (10) Culinary, (11) Music, (12) Publishing, (13) Art Performance, (14) Art, (15) Television andRadio, and (16) Advertising.Some of the students and alumni have pioneered businesses that have promising markets, but they experience problems in their implementation, which still requires guidance and assistance in managing the business. Through the activities of the Program Pengembangan Kewirausahaan (PPK) Industri Kreatif, it is expected to expand the marketing network, cooperation, strengthen management and get to know the model business so that the businesses involved can develop and compete in the market. The methods of PPK are carried out through socialization, registration of business proposals, selection, and assistance and training. At the end of this activity, 5 (five) new entrepreneurs were produced who were ready to become entrepreneurs and compete.
\end{abstract}

Keywords: Technopreneur; Entrepreneur; Creative Industry

Submitted : 2 Januari 2019 Revision : 25 Oktober 2019 Accepted : 17 Februari 2020 


\section{PENDAHULUAN}

Upaya untuk meningkatkan kualitas dan kuantitas penelitian dan pengabdian kepada masyarakat terus menurus dilakukan oleh Direktorat Jenderal Penguatan Riset dan Pengembangan (Ditjen Penguatan Risbang) untuk mencapai hasil penelitian dan pengabdian kepada masyarakat yang bermutu dan relevan dengan kebutuhan pembangunan nasional. Diharapkan hasil penelitian dan pengabdian kepada masyarakat yang bermutu tinggi dapat berkontribusi secara nyata kepada peningkatan daya saing bangsa. Secara empiris tidak dapat disangkal bahwa salah satu faktor utama pendukung kemajuan bangsa adalah adanya inovasi yang berbasis pada penelitian dan pengabdian kepada masyarakat yang baik dan bermutu.

Menyadari pentingnya peran penelitian dan pengabdian kepada masyarakat di Perguruan Tinggi, Ditjen Penguatan Riset dan Pengembangan selalu mendorong untuk terbangunnya pusat-pusat keunggulan (center of excellence) yang dapat memberikan jawaban atas berbagai persoalan baik di daerah, nasional dan global. Pengembangan pusat-pusat unggulan nasional dengan memanfaatkan kepakaran yang ada di berbagai perguruan tinggi dengan fokus tertentu, baik berbasis sektor, komoditas, maupun isu strategis nasional, selalu ditingkatkan dengan melibatkan berbagai disiplin keilmuan. Strategi yang dilakukan oleh Ditjen Penguatan Riset dan Pengembangan adalah dengan memberikan kewenangan yang lebih luas dalam pengelolaan penelitian kepada perguruan tinggimelalui program desentralisasi penelitian dan pengabdian kepada masyarakat, sedangkan untuk isu-isu nasional diwadahi melalui kompetitif nasional. Sementara itu, untuk isuisu yang dipandang strategis Ditjen Penguatan Riset dan Pengembangan dapat memberikan penugasan kepada Perguruan Tinggi yang mempunyai kompetensi yang tinggi dalam bidang yang bersangkutan melalui skema penugasan. (Direktorat Riset dan Pengabdian Masyarakat, 2018).

Kegiatan pengabdian kepada masyarakat dikelola langsung oleh Direktorat Riset dan Pengabdian Masyarakat (DRPM) Ditjen Risbang, Kementerian Riset dan Kementerian Riset, Teknologi, dan Pendidikan Tinggi Republik Indonesia untuk kompetitif nasional dan penugasan sedangkan untuk yang dikelola Perguruan Tinggi yaitu skema pengabdian desentralisasi. Pengelolaan pendanaan pengabdian kepada masyarakat mengikuti pola penelitian yaitu dengan mengelompokkan perguruan tinggi didasarkan pada kinerja pengabdian kepada masyarakat masing-masing perguruan tinggi.

DRPM melaksanakan suatu program dengan misi menghasilkan wirausahawirausaha baru dari kampus, melalui program terintegrasi dengan kreasi metode yang diserahkan sepenuhnya kepada perguruan tinggi melalui Program Pengembangan Kewirausahaan (PPK). Setiap perguruan tinggi berhak mengelola lebih dari satu program PPK. PPK boleh diusulkan oleh Fakultas/Jurusan dengan melibatkan sejumlah dosen yang berpengalaman berwirausaha dari berbagai disiplin ilmu. PPK melaksanakan pembinaan kepada tenant (calon wirausaha peserta PPK) melalui pelatihan manajemen usaha dengan sejumlah kegiatan kreatif lainnya untuk menghasilkan wirausaha baru yang mandiri berbasis iptek. Tenant harus meningkatkan keterampilan dalam menghasilkan produkdi program studi masing-masing. Pengelola PPK juga disarankan berkolaborasi dengan lembagalembaga yang terkait dengan pengembangan kewirausahaan, baik di dalam maupun di luar kampus, termasuk program pengembangan usaha produk intelektual kampus (PPUPIK) di perguruan tinggi masing-masing. (Direktorat Riset dan Pengabdian Masyarakat, 2018).

Melihat adanya peluang yang diberikan oleh Kementerian Riset, Teknologi dan Pendidikan Tinggi melalui DRPM, Ditjen Risbang maka STMIK Amikom Purwokerto sebagai Perguruan Tinggi yang memiliki visi "Unggul Dalam Pengembangan Ilmu Pengetahuan dan Teknologi Dengan Menyiapkan SDM Berkualitas yang Berjiwa Technopreneur" mengadakan serangkaian kegiatan PPK untuk para mahasiswa dan alumni dalam mewujudkan menjadi wirausaha yang siap terjun ke masyarakat.

Sudah sejak tahun 2005 hingga saat ini, STMIK Amikom Purwokerto telah melaksanakan banyak program-program pengembangan kewirausahaan seperti Career Day, Seminar Wirausaha Muda Baru, Workshop Animasi, Seminar Technopreneur dan beberapa kegiatan lainnya serta telah mencetak banyak wirausaha muda, yang 
berasal dari mahasiswa aktif maupun yang alumni. Menjadi entrepreneur dapat mengantarkan mahasiswa hidup lebih sejahtera, lebih mandiri, dan menolong banyak orang dalam mengatasi pengangguran (Kasali, dkk., 2010). Semangat dan tren wirausaha di kalangan mahasiswa semakin meningkat, terlebih dengan adanya dukungan kampus. Mahasiswa STMIK Amikom Purwokerto yang menjalankan kegiatan usahapun beragam baik sesuai dengan disiplin ilmu informatika dan komputer maupun yang non informatika.

Diangkatnya tema industri kreatif, dikarenakan industri kreatif merupakan industri yang memanfaatkan kreativitas, bakat, dan kemampuan individu untuk menciptakan kesejahteraan dan lapangan pekerjaan. Industri ini mengeksploitasi hasil karya seseorang seperti kerajinan tangan, karya tulis, musik, seni pertunjukan, film, kuliner, dan lain-lain.

Industri Kreatif dapat diartikan sebagai kumpulan aktivitas ekonomi yang terkait dengan penciptaan atau penggunaan pengetahuan dan informasi (Hesmondhalgh, 2007). Industri kreatif juga dikenal dengan nama lain Industri Budaya atau juga Ekonomi Kreatif (Howkins, 2013). Kementerian Perdagangan Indonesia menyatakan bahwa Industri kreatif adalah industri yang berasal dari pemanfaatan kreativitas, keterampilan serta bakat individu untuk menciptakan kesejahteraan serta lapangan pekerjaan dengan menghasilkan dan mengeksploitasi daya kreasi dan daya cipta individu tersebut (Fachri, 2017).

Ekonomi Kreatif terdiri dari periklanan, arsitektur, seni, kerajinan, desain, fashion, film, musik, seni pertunjukkan, penerbitan, Penelitian dan Pengembangan, perangkat lunak, mainan dan permainan, Televisi dan Radio, dan Permainan Video (Howkins, 2013). Industri kreatif dipandang semakin penting dalam mendukung kesejahteraan dalam perekonomian (Florida, 2003) dan bahwa peningkatan industri akan tergantung pada produksi pengetahuan melalui kreativitas dan inovasi (Mulyana, 2014).

Industri kreatif tercipta dari pemanfaatan serta keterampilan yang dimiliki oleh setiap individu untuk bisa membuat lapangan pekerjaan baru dan juga bisa menciptakan kesejahtraan di daerah. Terdapat berbagai macam sektor yang termasuk kedalam industri kreatif, diantaranya sektor arsitektur, periklanan, pasar barang seni, kerajinan, design, fashion, video, film dan fotografi, serta kuliner. Industri kreatif tidak hanya mengandalkan kreatifitas secara manual, namun saat ini industri kreatif sudah meluas hingga mencangkup sektor teknologi, seperti sektor industri permainan, industri musik, industri layanan komputer dan perangkat lunak atau aplikasi, dan industri pertelevisian (Fachri, 2017). Pertumbuhan sektor ekonomi kreatif sekitar 5,76 \%, artinya berada di atas pertumbuhan sektor listrik, gas dan air bersih, pertambangan dan penggalian, pertanian, peternakan, kehutanan dan perikanan, jasa-jasa dan industri pengolahan (Kementerian Komunikasi dan Informatika Republik Indonesia, 2015).

Badan Ekonomi Kreatif Indonesia (Bekraf) telah menetapkan 16 (enam belas) subsektor industri kreatif, yaitu Aplikasi dan Pengembang Permainan, Arsitektur, Desain Interior, Desain Komunikasi Visual, Desain Produk, Fashion, Film, Animasi dan Video, Fotografi, Kriya, Kuliner, Musik, Penerbitan, Periklanan, Seni Pertunjukan, Seni Rupa, Televisi dan Radio. Dengan adanya Bekraf menunjukkan bahwa pemerintah fokus terhadap pencapaian ekonomi kreatif sebagai tulang punggung perekonomian nasional (Badan Ekonomi Kreatif Indonesia, 2015).

Upaya untuk dapat menciptakan wirausaha di bidang industri kreatif terus diciptakan oleh berbagai elemen dan sektor dari Akademisi, Bussiness (Dunia Usaha), Government (Pemerintah Pusat/Daerah), dan Community (Komunitas) atau yang disingkat $\mathrm{ABG}+\mathrm{C}$. Perkembangan industri kreatif khusunya di Indonesia semakin luas dan semakin terus berkembang, seiring denganperkembangan tersebut kebutuhan sumber daya manusia punsemakin meningkat (Handani, dkk., 2016).

$$
\text { Misi Program Pengembangan }
$$

Kewirausahaan (PPK) yaitu memandu perguruan tinggi menyelenggarakan unit layanan kewirausahaan yang profesional, mandiri dan berkelanjutan, serta berwawasan ekonomi berbasis pengetahuan.Program ini harus dapat mandiri dan operasionalnya berkelanjutan, sehingga PPK diberi peluang untuk mampu menjadi unit profit. Melalui kegiatan PPK Industri Kreatif di STMIK Amikom Purwokerto dapat memotivasi mahasiswa sebagai pencipta lapangan pekerjaan, khususnya di bidang industri kreatif, 
dapat menjadi mahasiswa yang cerdas, kreatif dan inovatif tidak hanya penguasaan teori saja namun sampai dengan implementasinya di dunia usaha.

Tujuan dan target dari pelaksaanaan Program Pengembangan Kewirausahaan (PPK) Industri Kreatif di STMIK Amikom Purwokerto ini yaitu tercapat sejumlah 20 (dua puluh) peserta calon wirausaha baru dibidang industri kreatif yang berasal dari mahasiswa dan alumni. Dari sejumlah tersebut disaring dan diseleksi sehingga didapatkan sejumlah 5 (lima) wirausaha baru mandiri berbasis ipteks yang terjun di masyarakat dan bersaing di pasar.

\section{METODE}

Metode pelaksanaan kegiatan diawali dengan adanya sosialisasi kepada mahasiswa dan alumni STMIK Amikom Purwokerto melalui beberapa media seperti poster, pamphlet, pembuatan akun social media (Instagram dan Facebook) dan website hingga sosialisasi melalui seminar. Tahapan kedua dilakukan pola recruitment kepada mahasiswa dan alumni untuk mengikuti seleksi melalui pengiriman proposal usaha. Setelah proposal masuk akan dilakukan tahap review, hingga dinyatakan setidaknya 20 (dua puluh) proposal yang lolos dan dapat mengikuti pendampingan usaha. Kegiatan pendampingan usaha dilakukan dalam bentuk workshop dengan mengundang para praktisi dan narasumber yang kompeten bidang kewirausahaan serta pelaksanaan inkubasi.

Pembinaan jugameliputi adanya pelatihan model bisnis dan strategi bisnis, dimana dengan adanya perencanaan strategi bisnis yang tepat maka akan membantu perusahaan dalam menganalisis faktor ekternal dan internal untuk merumuskan dan merencanakaan strategi usaha yang tepat sehingga keuntungan atau profit akan tercapai sesuai tujuan perusahaan (Saputra dan Adnan, 2017).

Pada akhirnya dalam serangkaian kegiatan ini akan dipilih 5 (lima) wirausaha baru yang siap untuk memulai usahanya dan terjun dalam dunia bisnis yang sebenarnya. Kelima wirausaha baru tersebut akan mendapatkan bantuan modal usaha untuk mengembangkan usahanya.

\section{HASIL DAN PEMBAHASAN}

Hasil dari serangkaian kegiatan PPK ini diantaranya yaitu :

1. Sosialisasi

Diawali dari pelaksanaan sosialisasi kepada mahasiswa dan alumni STMIK Amikom Purwokerto tentang pelaksanaan kegiatan PPK, sosialisasi diadakan melalui beberapa media dan kegiatan baik online maupun offline. Gambar 1 berikut merupakan salah satu poster untuk informasi dan sosialisasi pelaksanaan kegiatan.

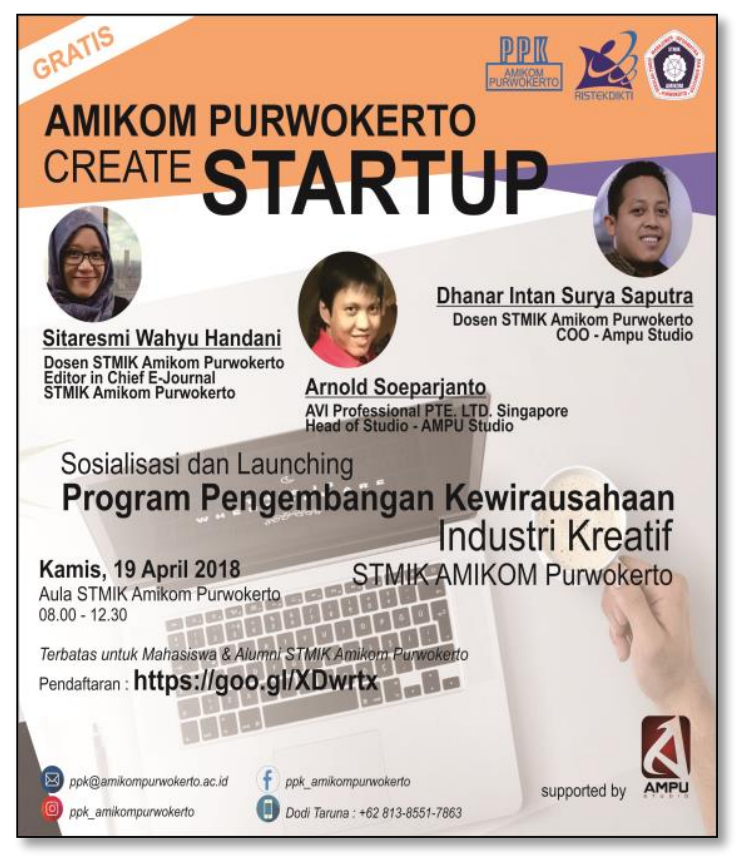

Gambar 1. Poster Sosialisasi kegiatan PPK

Dalam kegiatan sosialisasi diikuti sebanyak 200 peserta yang berasal dari 175 mahasiswa aktif dan 25 alumni STMIK Amikom Purwokerto yang berasal dari Program Studi Teknik Informatika dan Sistem Informasi. Dari adanya pelaksanaan sosialisasi ini, mereka menyatakan sangat antusias dikarenakan kegiatan semacam ini baru pertama kali dilaksanakan di STMIK Amikom Purwokerto.

2. Submit Proposal PPK dari Mahasiswa dan Alumni

Dari kegiatan sosialisasi diawal kegiatan, didapatkan setidaknya sebanyak 51 (lima puluh satu) proposal ide bisnis berbasis industri kreatif. Dari proposal tersebut kemudian di review untuk disaring dan dipilih menjadi 20 
ide bisnis yang siap untuk mengikuti pelatihan dan workshop hingga inkubasi.

3. Seleksi Proposal dan Proposal Terpilih

Sebanyak 20 (dua puluh) proposal lolos tahap inkubasi, semua proposal yang masuk kemudian dilakukan review dan ditentukan dari proposal terpilih untuk dapat diwujudkan menjadi usaha yang sebenarnya.Topik usaha tersebut meliputi di bidang sub sektor industri kreatif yaitu Pengembang Aplikasi dan Game, Film, Animasi dan Video serta Desain Komunikasi Visual. Lebih jelasnya apat dilihat dalam tabel 1 berikut :

Tabel 1. sebaran sub sektor Industri Kreatif usulan PPK

\begin{tabular}{llc}
\hline No. & \multicolumn{1}{c}{ Sub Sektor } & Jumlah \\
\hline 1. & Pengembang Aplikasi & 12 \\
\hline 2. & Game & 2 \\
\hline 3. & Film, Animasi dan Video & 1 \\
\hline 4. & Desain Komunikasi Visual & 5 \\
\hline & Total & 20 \\
\hline
\end{tabular}

4. Kegiatan workshop dan inkubasi untuk tim yang lolos

Semua tim yang lolos tahap seleksi proposal, diundang untuk mengikuti kegiatan pendampingan, workshop dan inkubasi. Kegiatan ini dilakukan untuk meningkatkan level dari ide usaha menjadi berwujud sebuah usaha.

Kegiatan pendampingan dan inkubasi terus dilaksanakan guna mendapatkan 5 (lima) tim yang siap menjadi wirausaha baru. Kegiatan pendampingan dan inkubasi ini bekerjasama dengan beberapa lembaga baik sebagai narasumber untuk workshop, maupun untuk inkubasinya itu sendiri. Lebih jelasnya dapat dilihat pada tabel 2 berikut ini :

Tabel 2. Daftar Kerjasama Inkubasi dan Workshop

\begin{tabular}{llc}
\hline No. & \multicolumn{1}{c}{ Lembaga } & \multicolumn{1}{c}{ Peran } \\
\hline 1. & $\begin{array}{l}\text { Kopkun Institute } \\
(\text { Inno Circle) }\end{array}$ & Lembaga Inkubasi \\
\hline
\end{tabular}

2. Qyta Trans Narasumber

\begin{tabular}{lllll}
\hline 3. & $\begin{array}{l}\text { Disperindag } \\
\text { Jateng }\end{array}$ & Prov. & $\begin{array}{l}\text { Pameran } \\
\text { Kreatif }\end{array}$ & Industri \\
\hline 4. & $\begin{array}{l}\text { PT. Ampu } \\
\text { Studio }\end{array}$ & Kreatif & Narasumber & \\
& & &
\end{tabular}

5. Pendanaan dan Rewards

Pendanaan dan Rewards diberikan kepada startup yang sudah siap untuk memulai usahanya dan benar-benar fokus dalam pengelolaan dan pengembangan bisnis. Rewards yang diberikan diantaranya bantuan modal, kepengurusan HKI (Hak atas Kekayaan Intelektual) dan penguatan ijin usaha

\section{Startup}

Hasil dari ide bisnis yang diusulkan dalam PPK Industri Kreatif di STMIK Amikom Purwokerto diantaranya adalah usulan dari tim PINTAR. Usulan dari tim PINTAR adalah mengusung media pembelajaran, pengenalan dan pelestarian kebudayaan Indonesia melalui teknologi Augmented Reality.

Tim PINTAR mewujudkan ide bisnisnya melalui penjualan media kaos yang dapat menampilkan konten Augmented Reality.Kaos ditujukan untuk pangsa pasar anak-anak dan pelajar, sehingga mereka dapat mengenal kebudayaan sekaligus belajar melalui media teknologi. Contoh rancangannya adalah sebagai berikut :

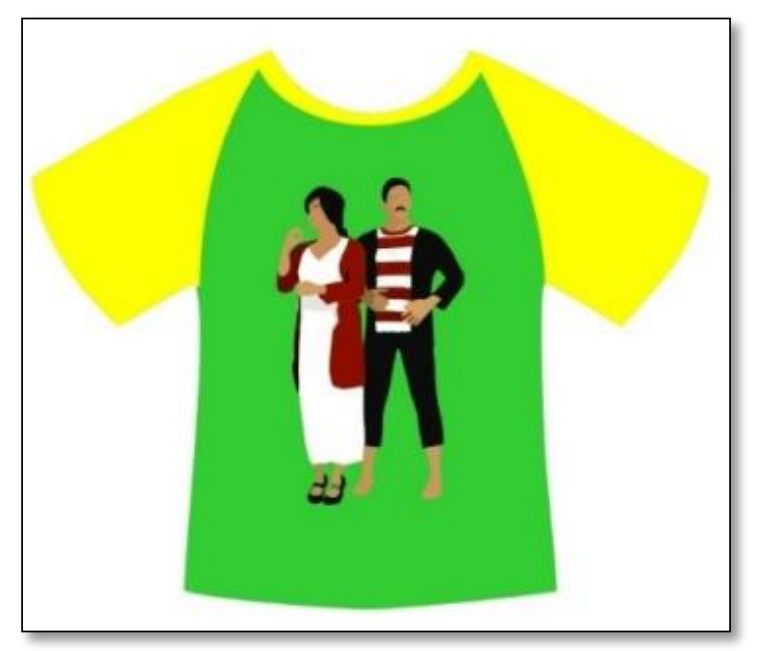

Gambar 2. Rancangan Ide Bisnis Kaos Augmented Reality oleh tim PINTAR 
Selain itu, ada juga usulan usaha dari peserta yaitu Bengkel Online (Bengkol). Platformonline yang mempertemukan antara pelaku usaha Bengkel dengan warga masyarakat yang membutuhkan layanan bengkel dan servis kendaraan bermotor. Usulan usaha dengan layanan ini sudah dapat dinikmati oleh warga masyarakat Purwokerto dan sekitarnya, walaupun masih dalam tahap pengembangan dan penyempurnaan.

Tim Bengkol sendiri menyampaikan bawah dari pelaksanaan kegiatan PPK ini dapat memperkuat bisnis proses yang diusulkan dari tim mereka sehingga mereka siap untuk menghadapi kebutuhan pasar dari masyarakat sekitar serta kebutuhan dari para pelaku usaha bengkel di Purwokerto

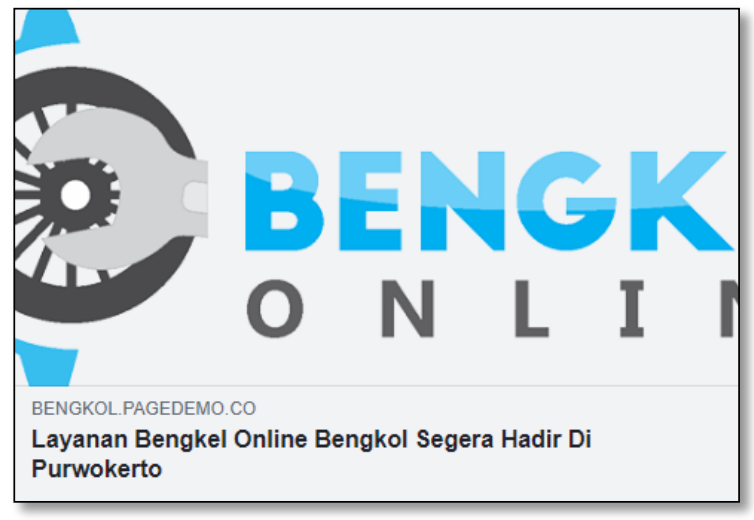

Gambar 3. Layanan Bengkol

Pada hasil akhir dalam serangkaian kegiatan PPK ini, baik tim Startup PINTAR maupun tim layanan Bengkol serta tim startup lainnya yang awalnya hanya dimulai dari adanya ide, saat ini dinyatakan telah siap untuk terjun dan bersaing dalam dunia wirausaha. Hal ini didapatkan dari adanya kegiatan pelatihan dan pendampingan yang dilaksanakan melalui seminar dan workshop serta pameran industri dibeberapa tempat.

Tim startup setidaknya telah memiliki model proses bisnis yang saat ini dirasa tepat. Setidaknya layanan yang mereka berikan telah berjalan dan mulai bisa diterima oleh masyarakat. Hal ini tentunya berdampak positif terhadap pelaksanaan kegiatan PPK ini. Sehingga harapan dari kegiatan PPK ini yaitu dapat membentuk wirausaha muda mandiri yang berasal dari Perguruan Tinggi, khususnya dalam hal ini STMIK Amikom Purwokerto dapat tercapai.

Para wirausahawan baru ini berasal dari ide dan gagasan mereka yang kemudian mengikuti alur dan tahapan demi tahapan yang telah dilaksanakan dan memiliki capaian berupa memperluas jaringan pemasaran, kerjasama, penguatan manajemen dan mengenal bisnis model sehingga usaha yang ditekuni dapat berkembang dan bersaing di pasar.

\section{SIMPULAN}

Kesimpulan yang diperoleh dengan adanya serangkaian kegiatan Program Pengembangan Kewirausahaan Industri Kreatif di STMIK Amikom Purwokerto antara lain adalah :

1. STMIK Amikom Purwokerto melalui kegiatan PPK yang sekaligus selaras dengan visi dan misi Lembaga dapat mewujudkan wirausaha-wirausaha baru berbasis teknologi atau dapat disebut sebagai Technopreneur.

2. Telah dilaksanakan serangkaian kegiatan PPK Industri Kreatif di STMIK Amikom Purwokerto dan melalui kegiatan ini terbentuk 20 (dua puluh) tim yang memiliki usulan ide bisnis yang siap untuk diwujudkan, salah satunya yaitu tim PINTAR yang melalui idenya berupa Kaos Kreatif Augmented Reality.

3. Pendampingan kepada para startup yang berhasil dan telah berjalan diharapkan terus dapat dilakukan untuk menjaga semangat dan pencapaian yang lebih baik lagi, hal ini dapat dilakukan melalui adanya kegiatan Inkubasi Bisnis baik yang dilakukan oleh Perguruan Tinggi atau dari berbagai lembaga Inkubator Bisnis Teknologi lainnya.

\section{UCAPAN TERIMA KASIH}

Terima kasih dan penghargaan yang setingginya disampaikan kepada Direktorat Riset dan Pengabdian Masyarakat (DRPM) 
Kementerian Riset Teknologi dan Pendidikan Tinggi Republik Indonesia (Ristekdikti) atas dukungan pembiayaan untuk pelaksanaan program ini dan STMIK Amikom Purwokerto atas dukungan dana pendamping dan fasilitasnya.

\section{DAFTAR PUSTAKA}

Badan Ekonomi Kreatif Indonesia.(2015). Tonggak Baru Ekonomi Kreatif Indonesiahttp://www.bekraf.go.id/subse ktor diakses pada 14 Agustus 2018.

Direktorat Riset dan Pengabdian Masyarakat. (2018). Panduan Penelitian dan Pengabdian Kepada Masyarakat - Edisi XII. Jakarta : Direktorat Riset dan Pengabdian Masyarakat, Direktorat Jenderal Penguatan Riset dan Pengembangan. Kementerian Riset, Teknologi dan Pendidikan Tinggi.

Fachri. (2017). Industri Kreatif. http://agribisnis.co.id/industri-kreatif/ diakses pada 14 Agustus 2018.

Florida, R. (2003). The Rise of the Creative Class : And How It's Transforming Work, Leisure, Community and Everyday Life. Paperback :Hazard Press.

Handani, S.W., Suyanto, M., dan Sofyan, A.F.(2016).Penerapan Konsep Gamifikasi Pada E-Learning Untuk Pembelajaran Animasi 3 Dimensi.Telematika, 9(1)
Hesmondhalgh, Industries

D.(2007).The

Cultural SAGEPublications.

Howkins, J. (2013). The Creative Economy: How People Make Money fromIdeas New Edition. UK : Penguin.

Kasali, R., Nasution, A.H., Purnomo, B.R., Ciptarahayu, A., Mirzanti, I.R., Rustiadi, S., Daryanto, H.K., Mulyana, A. (2010). Modul Kewirausahaan untuk Program Strata 1. Jakarta : Hikmah.

Kementerian Komunikasi dan Informatika Republik Indonesia. (2015). Ekonomi Kreatif adalah Pilar Perekonomian Masa Depan. https://kominfo.go.id/index.php/content/ detail/5277/Ekonomi-Kreatif-adalahPilar-Perekonomian-Masa-

Depan/0/berita diakses pada 14 Agustus 2018.

Mulyana, S. (2014). Peningkatan Kapabilitas Inovasi, Keunggulan Bersaingdan Kinerja melalui Pendekatan Quadruple Helix: Studi Pada IndustriKreatif Sektor Fashion. Jurnal Menajemen Teknologi, 13(3),304-320.

Saputra, D.I.S., dan Adnan, A.F.(2017). Analisis dan Rekomendasi StrategiE-Commerce Pada Usaha Kecil Menengah Batik Sokaraja.PRO BISNIS, 10 (1) 